\title{
JURY TRIAL FOR CRIMINAL CONTEMPTS: RESTORING CRIMINAL CONTEMPT POWER AND PROTECTING DEFENDANTS' RIGHTS
}

Contempt power enables the federal courts to secure the respect and obedience necessary to their task of defending the Constitution and administering the laws. The courts may institute criminal contempt proceedings against those who obstruct the administration of justice by engaging in a variety of actions, from courtroom disturbances to violations of court decrees. ${ }^{1}$ This power has been considered so important that courts have been permitted to use it without according defendant contemnors all the constitutional rights they enjoy in other criminal proceedings. There is no constitutional right to jury trial, ${ }^{2}$ and if the contempt is committed in the actual presence of the court, there are not even the procedural due process rights of notice and hearing, the court having power to punish summarily. ${ }^{3}$ Congress has specific-

1. 18 U.S.C. § 401 (1952) provides:

"Power of court.

"A court of the United States shall have power to punish by fine or imprisonment, at its discretion, such contempt of its authority, and none other, as-

(1) Misbehavior of any person in its presence or so near thereto as to obstruct the administration of justice;

(2) Misbehavior of any of its officers in their official transactions ;

(3) Disobedience or resistance to its lawful writ, process, order, rule, decree or command."

The original contempt statute was part of the Judiciary Act of 1789 , granting courts broad discretion to punish contempts. 1 STAT. 73, 83 (1789). A new contempt statute, couched in language substantially similar to that now used in 18 U.S.C. $\S 401$ (1952) was enacted in 1831. An Act declaratory of the law concerning contempts of court, 4 STAT. 487.

2. See note 52 infra.

3. FED. R. CRIM. P. 42(a). Nor is there a requirement of grand jury indictment. If the contempt is committed outside the court's actual presence, FED. R. CRIMr. P. 42(b) provides for notice and hearing. For judicial interpretations of "presence," see text at notes 33-46 infra.

FED. R. CrIM. P. 42 provides:

“(a) Summary Disposition. A criminal contempt may be punished summarily if the judge certifies that he saw or heard the conduct constituting the contempt and that it was committed in the actual presence of the court. The order of contempt shall recite the facts and shall be signed by the judge and entered of record.

"(b) Disposition Upon Notice and Hearing. A criminal contempt except as provided in subdivision (a) of this rule shall be prosecuted on notice. The notice shall state the time and place of hearing, allowing a reasonable time for the preparation of the defense, and shall state the essential facts constituting the criminal contempt charged and describe it as such. . . The defendant is entitled to a trial by jury in any case in which an act of Congress so provides.... If the contempt charged involves disrespect to or criticism of a judge, that judge is disqualified from presiding at the trial or hearing except with the defendant's consent." 
ally directed that jury trials be afforded contemnors who violate a court decree or order whenever the contemptuous conduct is also punishable as a separate criminal offense and occurs outside the presence of the court. ${ }^{4}$ Though the purpose of denying procedural safeguards, notably jury trial, was to enhance the effectiveness of the contempt power, ${ }^{5}$ the result has paradoxically been to limit its application. For appellate courts have been so reluctant to see criminal sanctions imposed upon defendants who were denied jury trials that they have warned trial courts to exercise self-restraint in the use of the contempt power and have also narrowed the substantive law of contempt.

\section{Iudicial Restraint}

\section{Criminal Contempt Law Restricted}

Self-restraint is a powerful theme throughout the law of criminal contempt. Although courts theoretically have broad discretionary power to punish as contempts any conduct which obstructs the administration of justice, ${ }^{6}$ appellate courts have stressed that restraint must be exercised in deciding when to use the power, what procedure to follow and what sentence to impose. ${ }^{7}$ This is especially so when the facts of a particular case are not readily apparent or where the obstructive acts are separate crimes as well as criminal con-

4. 18 U.S.C. $\$ 402$ (1952). See also 18 U.S.C. $\$ 3691$ (1952). However, there is no jury trial if the decree or order is entered "in any suit or action brought or prosecuted in the name of, or on behalf of, the United States." Penalties under $\$ 402$ are limited to a $\$ 1,000$ fine or six months in jail or both.

Other federal statutes provide jury trial in special contempt cases. See Notes of Advisory Committee on Rules following FED. R. CRIMr. P. 42 (b), 18 U.S.C. 2549 (1952), for a compilation of such provisions. See also Wright, et al., Civil \& Crininal Contempt in the Fideral Courts, 17 F.R.D. 167 (1955).

5. See text at note $\mathbf{5 2}$ infra; note 67 infra.

6. See text of 18 U.S.C. $\$ 401$ (1952) quoted at note 1 supra. The courts are restricted only by Supreme Court interpretations of $\S 401$. See, e.g., Nye v. United States, 313 U.S. 33 (1941); notes 40-41, 44 infra. Except where statutes provide otherwise, see note 4 supra, the courts have discretion to determine whether the contemptuous conduct warrants punishment, to find the facts and to set the amount of punishment. See, e.g., United States v. United Mine Workers, 330 U.S. 258 (1947); Ex parte Terry, 128 U.S. 289 (1888); United States v. Appel, 211 Fed. 495 (S.D.N.Y. 1913). Punishments are occasionally very severe. E.g., United States v. Thompson, 214 F.2d 545 (2d Cir.), cert. denied, 348 U.S. 841 (1954) (four years' imprisonment).

7. See, c.g., United States v. Appel, supra note 6 (advocating use of power only when facts are clear on their face without collateral inquiry); Nye v. United States, 313 U.S. 33, 49 (1941) (advocating restricted use of the contempt power to avoid, where possible, contempt determinations of guilt without jury trial) ; In re Michael, 326 U.S. 224, 227 (1945) (same); Offutt v. United States, 348 U.S. 11 (1954) (remanding for hearing before a different judge a disrespect contempt which had been properiy punished by the trial judge). See also Anderson v. Dunn, 19 U.S. (6 Wheat.) 204, 231 (1821) (sentence should be "the least possible ... to the end proposed"); United States v. United Mine Workers, supra note 6 , at 302-06 (factors determining amount of punishment).

For examples of the philosophy of self-restraint in state courts, see Edwards v. Edwards, 87 N.J.Eq. 546, 100 Atl. 60 (Ch. 1917) ; State v. Illario, 10 N.J. Super. 475, 77 A.2d 483 (App. Div. 1950). 
tempts. ${ }^{8}$ The appellate courts seem to be urging the trial courts to weigh in each case their need for the contempt power against the protection the defendant loses in not having a jury trial, and where the balance is strongly on defendant's side, as where the facts are doubtful, to refrain from citing for contempt. ${ }^{9}$ But the doctrine of self-restraint has been largely confined to the verbal level of appellate court control of contempt proceedings. ${ }^{10}$ When the courts have felt that trial judges were using the contempt power ill-advisedly, they have not reversed for abuse of discretion, but instead have narrowly construed the federal statute defining punishable contempts to hold that the conduct punished was not a contempt.

\section{False-Swearing Contempts}

A major restriction of contempt law has occurred in the area of false-swearing contempts due to a narrow construction of what constitutes an "obstruction to the administration of justice."11 At one time all material false swearing was considered punishable as a criminal contempt in the federal courts. ${ }^{12}$

8. In re Michael, supra note 7 (facts doubtful); In re Cantor, 215 Fed. 61 (2d Cir. 1914) (same) ; Ex parte Hudgings, 249 U.S. 378 (1919) (perjury); Farese v. United States, 209 F.2d 312 (1st Cir. 1954) (influencing a witness).

9. See cases cited notes 7,8 supra.

"[M] eticulous regard for ... separate categories of offenses must be had so that the instances where there is no right to jury trial will be narrowly restricted." Nye v. United States, 313 U.S. 33, 49 (1941). "The exercise by federal courts of any broader contempt power [than the "least adequate to the end proposed." Anderson v. Dunn, 19 U.S. ( 6 Wheat.) 204, 231 (1821)] would permit too great inroads on the procedural safcguards of the Bill of Rights, since contempts are summary in their nature, and leave determination of guilt to a judge rather than a jury." In re Michael, 326 U.S. 224, 227 (1945).

10. No reversals have been grounded solely on failure to exercise self-restraint. Rccently, however, concern with self-restraint has lead some courts to remand for stricter procedural protections. In re Murchison, 349 U.S. 133 (1955) : Offutt v. United States, 348 U.S. 11 (1954); In re Oliver, 333 U.S. 257 (1948); Matusow v. United States, $22^{\prime}$ F.2d 335 (5th Cir. 1956).

11. Section 401(1) requires that misbehavior, to be punished as contempt, must occur "in the presence of the court or so near thereto as to obstruct the administration of justice." 18 U.S.C. $\$ 401$ (1) (1952). Although the language of the statute suggests that misbchavior occurring in the court's presence need not obstruct the administration of justice in order to be punished, courts have taken the position that obstruction is an essential element of a contempt. E.g., Nye v. United States, 313 U.S. 33 (1941); Ex parte Hudgings, 249 U.S. 378 (1919). For a discussion of "obstruction," see text at notes $40-47$ infra.

12. E.g., In re Schulman, 177 Fed. 191 (2d Cir. 1910); In re Steiner, 195 Fed. 299 (S.D.N.Y. 1912) ; United States v. Appel, 211 Fed. 495 (S.D.N.Y. 1913) ; In re Ulmer, 208 Fed. 461 (W.D. Ohio 1913). However, up to 1906, the contempt defendant in the federal law courts could under oath deny the facts of the contempt and, unless the facts of the contempt were clear on their face, be punishable only for the crime of perjury. This privilege of purgation of contempt by oath was eliminated in the federal courts in 1906 . Ste United States v. Shipp, 203 U.S. 563, 574 (1906); Clark v. United States, 289 U.S. 1, 19 (1923) ; Curtis \& Curtis, The Story of a Notion in the Law of Criminal Contempt, $41 \mathrm{Hukv}$. L. REv. 51 (1927) ; Moskovitz, Contempt of Injunctions, Civil and Crininal, 43 Colux. L. REv. 780, 817 (1943). 
Currently, however, perjury alone does not constitute a criminal contempt.13 Something more must be shown in addition to the perjury to evidence an obstruction to the administration of justice. ${ }^{14}$ The courts say there must be "defiance of the court"15 or a "blocking of the inquiry."16 Courts have found the requisite obstruction in sham inability to remember, "patent" false swearing and unjustified refusals to testify. ${ }^{17}$ They have found blocking of the inquiry when a prospective juror on voir dire examination falsely testified on a material matter and when a lawyer falsely represented himself to be a member of the local bar. ${ }^{18}$ But when the facts of a witness's false-swearing contempt have been somewhat uncertain, courts have reversed contempt citations, not for failure of proof beyond a reasonable doubt, but on the ground that "obstruction" was not shown. ${ }^{10}$ In some cases the issue of untruthfulness was in doubt either because the witness's own statement considered by itself

13. In ro Michael, 326 U.S. 224 (1945); Ex parte Hudgings, 249 U.S. 378 (1919). Sce also Note, 7 Vand. L. Rev. 272 (1954).

14. In re Michael, supra note 13; Ex parte Hudgings, stlpra note 13 ; United States $e x$ rel. Johnson v. Goldstein, 158 F.2d 916 (7th Cir. 1947); United States v. Arbuckle, 48 F. Supp. 537 (D.D.C. 1943).

It is gencrally agreed that perjury obstructs justice. See United States v. Norris, 300 U.S. 564, 574 (1937); In re Michael, supra; United States v. Arbuckle, supra. Prior to 1919 there was little doubt that perjury equally obstructed the adniinistration of justice, due to the delay and expense it often causes, and the possible miscarriage of justice that may result. However, in 1919 the Supreme Court held that perjury alone does not constitute an obstruction to the administration of justice. Ex parte Hudgings, supra.

Some federal courts have nevertheless continued to hold that material false swearing obstructs the administration of justice and is punishable as contempt. E.g., United States v. McGovern, 60 F.2d $\$ 80$ (2d Cir.), cert. denied, 287 U.S. 650 (1932) (unsatisfactory explanation of disposition of large sum of money); Bowles v. United States, 50 F.2d 848 (4th Cir. 1931) (disbarred attorney falsely represented himself to be a member of the bar); United States v. Dachis, 36 F.2d 601 (S.D.N.Y. 1929) (grand jury witness falsely claimed not to have certain papers); United States v. Ford, 9 F.2d 990 (D. Mont. 1925).

15. United States v. Arbuckle, supra note 14, at 538; see Clark v. United States, 289 U.S. 1, 10-12 (1933).

16. United States v. Appel, 211 Fed. 495 (S.D.N.Y. 1913). See also In re Michael, 326 U.S. 224 (1945) (obstructing or halting the judicial process); Ex parte Hudgings, 249 U.S. 378, 383 (1919) ("obstruction to the performance of judicial duty").

17. Ex parte Hudgings, supra note 16 (contumacious refusals to testify); Schleier v. United States, 72 F.2d 414 (2d Cir.), cert. denied, 293 U.S. 607 (1934) (inability to remember source of large sum of money); Lang v. United States, 55 F.2d 922 (2d Cir.), cort. dismissed, 286 U.S. 523 (1932) (bank treasurer's sham inability to remember handling of unusually large bank account under his supervision); O'Connell v. United States, 40 F.2d 201 (2d Cir. 1930), cert. dismissed, 296 U.S. 667 (1936) (grand jury witness's sham failures to remember); United States v. Appel, supra note 16 (sham testimony).

18. Clark v. United States, 289 U.S. 1 (1933) (juror's willful false swearing on voir dire) ; Bowles v. United States, 50 F.2d 848 (4th Cir. 1931) (disbarred attorney falsely represented to be a member of the bar). See also Laughlin v. United States, 151 F.2d 281 (D.C. Cir.), ccrt. denied, 326 U.S. 777 (1945) (attorney filed affidavits falsely charging judicial bias); United States v. Ford, 9 F.2d 990 (D. Mont. 1925) (attorney presented false documents to court).

19. E.g., In re Michael, 326 U.S. 224 (1945) ; Ex parte Hudgings, 249 U.S. 378 (1919). 
seemed false but not patently so, ${ }^{20}$ or because his statement was contradicted by the weight of other witnesses' testimony. ${ }^{21}$ In other cases, a witness admitted the falsity of his statements but claimed not to have lied willfully, and the evidence of willfulness was not absolutely certain.22

The restricted law of false-swearing contempts which results from these cases is irrational in terms of the standards which the courts claim they are using and has proved confusing to the courts themselves. Though the courts purport to decide when false swearing is a contempt by inquiring whether the administration of justice has been obstructed, in fact they have not done this. All material false swearing blocks the court's inquiry and defies the court's right to obtain testimony. ${ }^{23}$ The lie of a juror or a lawyer is not necessarily more obstructive than the lie of a witness, ${ }^{24}$ yet the contempt power does not reach the latter's conduct unless the lie is clear on its face. ${ }^{20}$ Doubtful false swearing by a witness may be even more obstructive than apparent false swearing, yet only the latter is held a criminal contempt. ${ }^{20}$ This irrational approach has made it difficult for courts to know what is now a contempt. For example, the First Circuit has suggested that neither a sham refusal to testify nor a bad-faith claim of the privilege against self-incrimination can constitute a criminal contempt under any circumstances. ${ }^{27}$ But courts have repeatedly declared that both types of conduct are within the contempt statute. ${ }^{28}$ Thus, the scope of the contempt power has not only been narrowed, but its precise limits have been hopelessly obscured.

The root of the difficulty lies in the courts' failure to realize just how they have narrowed the law of false-swearing contempts. In each of the witness false-swearing cases where the contempt finding was reversed, the facts were doubtful, and the courts made abundantly clear that their concern was the absence of jury trial. ${ }^{29}$ Prompted to restrain the use of the contempt power because of the absence of jury trial, the courts quite reasonably have insisted on an extraordinarily high standard of proof-roughly equivalent to the stand-

20. E.g., Ex parte Hudgings, supra note 19.

21. In re Michael, 326 U.S. 224 (1945); United States ex rel. Johnson v. Goldstein, 158 F.2d 916 (7th Cir. 1947).

22. United States v. Arbuckle, 48 F. Supp. 537 (D.D.C. 1943).

23. The courts concede that false swearing deceives and obstructs justice, that it causes delay and expense, and that it may even defeat the "sole ultimate objective of a trial." In re Alichael, 326 U.S. 224, 227 (1945). See also United States exr rel. Johnson v. Goldstein, 158 F.2d 916 (7th Cir. 1947) ; United States v. Arbuckle, supra note 22.

24. See In re Steiner, 195 Fed. 299, 303 (S.D.N.Y. 1912) ; if. In re Presentment by Grand Jury of Ellison, 44 F. Supp. 375 (D. Del.), aff'd, 133 F.2d 903 (3d Cir. 1942), cort. denied, 318 U.S. 791 (1943); United States v. Karns, 27 F.2d 453 (D. Okla. 1928).

25. See notes 17-22 supra and accompanying text.

26. See notes 16-22 supra and accompanying text.

27. Carison v. United States, 209 F.2d 209, 214 (1st Cir. 1954).

28. See cases cited at note 17 supra; Note, 30 Notre DAME L.J. 284 (1955).

29. See, e.g., In re Michael, 326 U.S. 224 (1945) ; Ex parte Hudgings, 249 U.S. 378 (1919) ; Matusow v. United States, 229 F.2d 335 (5th Cir. 1956) ; Carlson v. United State's, 209 F.2d 209 (1st Cir. 1954). 
ard for directing a civil verdict. ${ }^{30}$ But once having verbalized this high standard in terms of palpable certainty, courts then came to view the evidentiary standard as a rule of substantive law. The early requirement that perjury must be "apparent on its face" 31 to be punishable as contempt became a rule that "obstruction" and "defiance" must be shown in addition to the perjury..$^{32}$ The extra amounts of evidence of perjury were thought of as separate substantive elements of the offense of criminal contempt. But these extras never existed as separate elements; hence it is no wonder that courts now have difficulty locating them. If the absence of jury trial prompts courts to set high standards of proof for contempts, the pertinent inquiry should be whether it is better to have jury trials or maintain extraordinarily high standards of proof. But rather than make this inquiry, courts have curtailed the substantive law of contempt haphazardly, without precise regard either to the need for the contempt power or the rights of defendants.

\section{"Presence" of the Court and "Near Thereto"}

Modern courts have also exhibited their unwillingness to impose punishment for contempt without jury trial by narrow construction of the statutory requirement that misbehavior occur either "in the presence of the court" or "sufficiently near thereto to obstruct the administration of justice." 33 In $E x$ parte Savin ${ }^{34}$ the Supreme Court had defined "presence of the court" as including, at least while the court is in session, all areas reserved for the use of the court or its officers, including hallways. The Court thereupon affirmed a contempt conviction based on efforts to influence a witness in the court's hallway and witness room. But recently in Farese v. United States ${ }^{35}$ the

30. See 5 Moore, Federal Practice $\int 50.02$ (2d ed. 1951).

31. United States v. Appel, 211 Fed. 495, 496 (S.D.N.Y. 1913). See In re Cantor, 215 Fed. 61 (2d Cir. 1914), and cases cited at notes 7-8 supra, requiring that facts be clear on their face, without collateral inquiry, so that no observer who was present could doubt them. The use of this test was affirmed in In re Michael, 326 U.S. 224, 228 (1946).

32. See cases cited at notes 13-16 supra.

33. 18 U.S.C. $\$ 401(1)$ (1952). There are three separate definitions of "presence," each with different legal significance in criminal contempt law. (1) Actual presence means in the sight or hearing of the court, under such circumstances that the facts are known to the judge without confession or collateral inquiry. These contempts may be punished summarily, without hearing. FED. R. CRMM. P. 42(a). (2) Presence of the coutrt includes any place where court or grand-jury sessions are held, including hallways and rooms for witnesses and jurors. One judge has said that presence is "used in a brooding, metaphorical sense broader than misbehaviour in the 'actual presence' of the judge ...." Carlson v. United States, 209 F.2d 209, 213 (1st Cir. 1954). (3) Sufficiently near to the prescnce of the court to obstruct the administration of justice currently means within hearing distance of the court, but not necessarily under such circumstances that the judge knows from firsthand evidence who is responsible for the contempt (see (1) supra). For a discussion of definitions (2) and (3), see text at notes 34-46 infra. See, generally, Annot., 42 A.L.R.2d 970 (1955).

34. 131 U.S. 267,277 (1889).

35. 209 F.2d 312 (1st Cir. 1954). 
First Circuit-admittedly motivated by the doubtfulness of the facts and the absence of jury trial ${ }^{36}$-reversed a one-year criminal contempt sentence, finding that an alleged threatening conversation with a witness's wife in the hallway of the court was not "in the presence of the court." The court took the narrow position that in order to construe the court's presence to include the hallway, the court's "business" must be "currently transacted" there, as when the hallway is being used "as an assembly place for witnesses in attendance upon the court."37

Prior to 1941 any set of facts which obstructed the administration of justice, or showed a tendency to do so, was considered "sufficiently near" the presence of the court to constitute a criminal contempt. Obstruction was interpreted to include any act tending to interfere with or pervert the performance of judicial duty, and courts therefore exercised contempt power over acts committed miles away from the scene of the courtroom. ${ }^{38}$ But in Nye v. United States ${ }^{39}$ the Supreme Court overruled a decision of twenty-three years' standing ${ }^{40}$ to redefine "near" the "presence of the court" to mean the immediate geographic vicinity of the courtroom. Since the contempt statute measures nearness in terms of whether the contemptuous conduct "obstructs the administration of justice," 41 the Court also had to redefine "obstruction" in order to establish the geographic limits of the contempt power. The Court looked for a showing of conduct "disturbing to quiet and order" or "actually interrupting the court in the conduct of its business." 42 Thus, contempts ocurring "near" the "presence of the court" must apparently be in the vicinity of the courthouse and also be accompanied by noise or some other disturbance. This narrow interpretation of what constitutes a contempt occurring near the court's presence presumably is not applicable to contempts occurring in the

36. Farese v. United States, 209 F.2d 312, 314, 315, 317 (1st Cir. 1954).

37. Id. at 317. Cf. Higgins v. United States, 160 F.2d 223 (D.C. Cir. 1946), ccrt. denied, 331 U.S. 840 (1947) (attempt to influence a juror walking in the hallway of the court during an adjournment was contempt occurring in the presence of the court).

38. E.g., Toledo Newspaper Co. v. United States, 247 U.S. 402 (1918) (newspaper criticism of pending court proceedings) ; Sinclair v. United States, 279 U.S. 749, 765 (1929) (spying on jurors) ; In re Brule, 71 Fed. 943 (D. Nev. 1895) (bribing witness out of court) ; see Warring v. Colpoys, 122 F.2d 642 (D.C. Cir. 1941) ; Wimberly v. United States, 119 F.2d 713 (5th Cir. 1941) ; Thomas, Problems of Contenpt of Court 63-74 (1934).

39. 313 U.S. 33 (1941).

40. Toledo Newspaper Co. v. United States, 247 U.S. 402 (1918).

41. 18 U.S.C. $\$ 401$ (1) (1952).

42. Nye v. United States, 313 U.S. 33, 52 (1941). There is considerable historical support for the Nye decision. See Frankfurter \& Landis, Power of Congress over Procedure in Criminal Contempts in "Inferior" Federal Courts-A Study in Scparation of Pozvers, 37 Harv. L. Rev. 1010 (1927) ; Thonas, op. cit. supra note 38, at 53-74. However, although the history of the contempt statute of 1831 was considered by the Court in Toledo Newspaper Co. v. United States, 247 U.S. 402, 403-07, 416-20, 422, 423 (1918), it nevertheless upheld a broader construction of the statute. Concern for history thus appears to be the explanation given for, but not the cause of, the $N y e$ decision. 
court's presence. ${ }^{43}$ Nye indicated this by pointing out that bribing a witness in the presence of the court is a contempt, even if no noise or disorder occurs. ${ }^{44}$ With regard to the Court's motivation, it should be noted that the facts of the earlier case which it overruled were clear, ${ }^{45}$ whereas in Nye the facts were not certain, and the Court emphasized the importance of the fact that defendant had no right to jury trial. ${ }^{46}$

The resulting definitions of "presence of the court" and "near thereto" bear little relation either to the courts' need for the contempt power or to defendants' need for protection from judicial determination of doubtful facts. From the standpoint of need for the contempt power, it is difficult to see more obstruction to the judicial process in tampering with witnesses in hallways of a courthouse than in threatening them miles away. Further, the confusion which has resulted from courts' failure to understand that there are separate definitions of "obstructing the administration of justice," depending on whether the obstruction occurs in or near the court's presence, leaves the courts with vague criteria for determining when the contempt power may be used. ${ }^{47}$ From the standpoint of protecting the defendant, the new definitions do exclude some conduct from the scope of the contempt power, ${ }^{48}$ but doubtful fact situations may still arise within or near the court's presence. Courts will rarely have certain knowledge of contempts occurring in grand-jury courtrooms, in witness and jury rooms, or in hallways; nor will the court necessarily know with certainty who is disturbing the court by outside noise. ${ }^{49}$

43. For cases noting this distinction, see In re Presentment by Grand Jury of Ellison, 44 F. Supp. 375 (D. Del.), aff'd, 133 F.2d 903 (3d Cir. 1942), cert. denied, 318 U.S. 791 (1943); Farese v. United States, 209 F.2d 312, 316 (1st Cir. 1954). See also Carlson v. United States, 209 F.2d 209 (1st Cir. 1954) ; Thomas, op. cit. supra note 38, at 63, 64.

44. Nye v. United States, 313 U.S. 33, 48 (1941). Further, the Court stated that defendants' action in wrongfully persuading an administrator to seek the dismissal of the estate's wrongful death action was "an obstruction in the administration of justice, as evidenced by the long delay and large expense which the reprehensible conduct . . . entailed." Id. at 52; $c f$. Pendergast v. United States, 317 U.S. 412 (1943).

45. Toledo Newspaper Co. v. United States, 247 U.S. 402 (1918). Published newspaper articles were the subject matter of the contempt.

46. Nye v. United States, 313 U.S. 33, 39, 49, 53 (1941).

47. In considering whether conduct occurring in the court's presence is punishable as contempt, many courts have looked for breaches of order and decorum, which identify contempt usar the court's presence. E.g., Carlson v. United States, 209 F.2d 209 (1st Cir. 1954) ; Farese v. United States, 209 F.2d 312 (1st Cir. 1954). See also In re Michael, 326 U.S. 224, 227 (1945) ; United States v. Arbuckle, 48 F. Supp. 537 (D.D.C. 1943).

48. The following cases illustrate contempts no longer punishable as not occurring within the presence of the court: Cammer v. United States, 24 U.S.L. WEEK 4131 (U.S. March 13, 1956) (alleged attempt to influence jurors) ; Farese v. United States, supra note 47 (threatening witness through his wife); Klein v. United States, 151 F.2d 286 (D.C. Cir. 1945) (attorney refused to return to court and continue case); Wimberly v. United States, 119 F.2d 713 (5th Cir. 1941) (attempt to influence a juror); Millinocket Theatre, Inc. v. Kurson, 39 F. Supp. 979 (D. Me. 1941) (destruction of evidence).

49. Nor will the judge necessarily see or hear every contempt occurring within the courtroom. 
Thus, the contempt power is again narrowed and confused by courts concerned with the absence of jury trial in specific cases where facts are doubtful and, often, where the acts alleged constitute separately punishable crimes. ${ }^{50}$

\section{Use of the Criminal Contenpt Power}

Determining the proper scope of the contempt statute and the right of a defendant contemnor to a jury trial requires an examination of the need for the contempt power itself. Courts have traditionally considered the contempt power necessary to enable them to administer justice and thereby protect the Constitution. ${ }^{51}$ The courts have assumed that necessity equally requires both the power and its summary use-without the constitutional protection of jury trial, normally guaranteed in federal criminal prosecutions. ${ }^{\mathrm{w2}}$ But the courts

50. Two recent cases further illustrate curtailment of the contempt power prompted by judicial reluctance to punish defendants who were denied jury trial. In Cammer v. United States, 24 U.S.L. WEEK 4131 (U.S. March 13, 1956), the Court reversed a finding that an attorney was in contempt for having wrongfully influenced jurors. The reversal was based on a ruling that attorneys are not "officers of the court" for purposes of 18 U.S.C. $\S 401(2)$ (1952). Before Cammer it had been assumed that attorneys were officers of the court for purposes of the contempt statute when engaged in "official transactions." See Clark v. United States, 289 U.S. 1, 12 (1933) ; Farese v. United States, 209 F.2d 312, 315 (1st Cir. 1954). But see Schmidt v. United States, 124 F.2d 177 (6th Cir. 1941).

In Farese v. United States, supra, the First Circuit stated that threatening a witness's wife does not per se constitute an obstruction to the administration of justice. But in Sinclair v. United States, 279 U.S. 749, 762 (1929), the Court had held that an attempt to influence a juror constitutes contempt even if the juror does not know of the attempt and it fails.

51. See Gompers v. Buck Stove \& Range Co., 221 U.S. 418, 450 (1911) ; Bessette v. W. B. Conkey Co., 194 U.S. 324, 336, 337 (1904); Ex parte Terry, 128 U.S. 289 (18\$8); United States v. Hudson, 11 U.S. (7 Cranch) 31, 34 (1812).

52. See Fisher v. Pace, 336 U.S. 155, 159-60 (1948); In re Debs 158 U.S. 564, 594, 595 (1895) ; Eilenbecker v. Plymouth County, 134 U.S. 31, 36 (1890). See also cases citcd note 51 supra; 5 MOORE, FeDERAL PRACTICE If 38.33 (2d ed. 1951) ; 5 id. $\{38.08$ [5] (collecting citations).

Absence of jury trial has also been justified on two other "rationales," neither of which support the conclusion reached. First, courts have argued that historically there never was a right to jury trial in contempt proceedings. See, e.g., In re Debs, supra at 596; Eilenbecker v. Plymouth County, supra at 36. However, in England there was a right to jury trial for contempts not committed in the actual presence of the court, until the early eighteenth century (when Star Chamber influence may have led to the change in procedure in the law courts). A mistake in reporting had, unfortunately, long hidden this fact from English and American courts. See Fox, The History of Contedrpt of Court 5-13, 48-55, 202-26 (1927); Frankfurter \& Landis, supra note 42; THonas, op. cit. supra note 38 , at 5 .

Secondly, courts have indulged in merry-go-round jurisprudence by denying the right to jury trial because contempt is sui generis. This phrase is merely descriptive of the procedure courts have elected to use in exercising their contempt power. Describing the conclusion does not provide a basis for reaching it. The descriptive words do not change the nature of the crime or the punishment. See Ex parte Grossman, 267 U.S. 87, 117 (1925) ; Bessette v. W. B. Conkey Co., 194 U.S. 324, 326 (1904); Thomas, op. cit. supra at $1-11$. 
have erred in assuming that the need for the contempt power justifies its summary use in all cases..$^{53}$

\section{Need for Contempt Power}

Although the normal operation of the criminal law might fully provide for the prosecution of contennors, granting courts discretion to initiate criminal contempt proceedings and punish contempts secures four important benefits to the administration of justice which would be partially lacking if courts had to rely on prosecutions by district attorneys in other courts. ${ }^{54}$ These benefits are speed of prosecution and punishment necessary for some conduct, increased deterrence of contemptuous conduct, avoidance of delays in the judicial process, and promotion of the dignity of the courts. When a contempt disrupts the decorum of the courtroom or affronts the dignity of the judge, arrest and later trial and punishment under regular criminal procedure could be used to restore order. However, this type of contempt may often require immediate punishment in order to provide for the administration of justice in the principal proceedings, as when the judge finds it necessary to bar a contemnor from the courtroom. ${ }^{55}$ Further, assured judicial prosecution may well increase the deterrent effect on would-be contemnors. For example, the man contemplating disobedience to a court order by refusal to produce papers or stop picketing may be more deterred from doing so by the knowledge that his refusal may bring immediate prosecution and punishment at the court's discretion than if prosecution depended on the delayed exercise of discretion by the district attorney.

The contempt power avoids delays to the judicial process in two ways. First, the facts of many criminal contempts must often be resolved in order to adjudicate the matters of the case in which the contempt occurred. For example, it is important to know immediately whether a juror was bribed or a witness testified falsely or a party was wrongfully persuaded to move for dismissal of an action. Immediate judicial investigation avoids the unnecessary duplication which a hearing in the principal case followed by a separate action to punish the contemnor would entail.58 Secondly, if contempts committed within the court's sight were to be prosecuted by a district attorney as a

53. See, generally, Beale, Contempt of Court, Criminal and Civil, 21 Harv. L. Rev. 161 (1908); Frankfurter \& Landis, supra note 42; Nelles, The Summary Pozver to Punish for Contcmpt, 31 Colun. L. Rev. 956 (1931); Thomas, op. cit. supra note 38; Comment, 57 YALE.L.J. 83 (1947).

54. For a discussion of district attorneys' discretion in prosecution and the delays and failures to prosecute that may result, see Comment, 65 YALE L.J. 209, 210-11 (1955). See also Nye v. United States, 313 U.S. 33, 53-54 (1941) (dissenting opinion).

55. See, e.g., Anderson v. Dunn, 19 U.S. (6 Wheat.) 204, 231 (1821) (contemnor confined in jail until the end of congressional session). Further, the judge may feel it necessary to keep a contemnor from exerting continued influence on a witness or juror in a current proceeding. See, e.g., Sinclair v. United States, 279 U.S. 749 (1929) (spying on and intimidating jurors); In re Brule, 71 Fed. 943, 946 (D. Nev. 1895) (persuading and encouraging potential witness, wanted by the court, to avoid service of subpoena).

56. See In re Debs, 158 U.S. 564, 594, 595 (1895). 
normal criminal offense, delays would result whenever judges were called from their judicial duties to testify as witnesses. In this situation a further disadvantage would be the impairment of a judge's dignity in having to submit to cross-examination as to matters he has seen in his own courtroom. And finally, possession of the criminal contempt power by the courts enhances the dignity of the judicial process itself. The power provides the threat and the means for securing the respect and obedience to which the courts are entitled. ${ }^{57}$

To gain these advantages of judicial prosecution the contempt power should extend to all obstructions to the administration of justice. As long as courts have discretion to decide in each case whether any particular conduct interferes with the judicial process sufficiently to warrant punishment, there is no reason for arbitrarily restricting the scope of the power. If a requisite standard of proof is met, no distinctions should be made which depend on whether the facts of an obstruction are patently clear or susceptible of some slight doubt. ${ }^{\text {s8 }}$ Distinctions based on geographic lines are equally unwarranted. Nor should it matter that the contemptuous conduct is also a separately punishable offense. The contempt power protects the judicial process. If the community also wants redress against the wrong, the district attorney can exercise his discretion to punish for violation of the community's laws. ${ }^{59}$ While it might be thought that use of the contempt power could become a device for circumventing evidentiary rules applicable to particular crimes, such as the twowitness rule for perjury convictions, the courts can readily prevent this. The two-witness rule was judicially created, ${ }^{60}$ and if courts find its preservation desirable, they can insist that it be complied with whenever the contempt power is invoked to punish conduct which is within the scope of the perjury statute. ${ }^{61}$ If contempt findings are to be reversed, the only grounds should be improper procedure, insufficiency of the evidence or an abuse of discretion by the trial court in use of the power. Inconsistent and irrational decisions which hold that some conduct does obstruct justice but is not technically a contempt should be rejected.

\section{Need to Deny Jury Trial}

Although there is need for courts to be able to initiate criminal contempt proceedings, the reasons justifying the power do not warrant its use without

57. See Sacher v. United States, 343 U.S. 1, 8, 9 (1952) ; Ex parte Terry, 128 U.S. 289 (1888).

58. The criminal standard of proof, guilt beyond a reasonable doubt, applies to all criminal contempts. See, c.g., United States v. Fleischman, 339 U.S. 349, 363 (1950); Gompers v. Bucks Stove \& Range Co., 221 U.S. 418, 444 (1911).

59. For example, courts have long held that false swearing may be punished as perjury and also as criminal contempt. See Ex parte Hudgings, 249 U.S. 378, 383 (1919) ; Unitcd States v. Johansen, 36 F. Supp. 30 (S.D.N.Y. 1940).

60. 7 WigMORE, EVIDENCE $\$ 2040$ (3d ed. 1940).

61. 18 U.S.C. $\$ 1621$ (1952). For a recent discussion of the two-wituess rule, see Note, $53 \mathrm{Mich}$. L. Rev. 1165 (1955). 
jury trial in all cases. When breaches of courtroom decorum, such as noise, violence or disrespect, occur in the sight or hearing of the judge, then summary punishment without hearing or jury trial is necessary to restore order and prevent "demoralization of the courts' authority." ${ }^{2}$ The court must have power to bar the contemnor from the courtroom without delay. ${ }^{83}$ Furthermore, if hearings or jury trials were required in these situations, the judge might be called as a witness, and delays to the judicial process and loss of judicial dignity would result. ${ }^{04}$ But neither these factors nor the other reasons that justify the contempt power require the denial of a contemnor's right to a jury trial, unless the contempts occur in the courtroom where it is apparent to the judge that the contempt was committed and that the accused contemnor was responsible. ${ }^{65}$

Courts have always recognized that different procedures should be used in prosecuting contempts depending on whether the contempt occurred in the actual presence of the court-within the sight or hearing of the judge. The Supreme Court has consistently held that when contempts occur outside the court's actual presence, summary punishment is not warranted, and the contemnor is entitled to the constitutional guarantees of notice and hearing, right to counsel and the right to present his own witness and cross-examine others. ${ }^{66}$ But the courts have failed to realize that the extra delay interposed by jury trial of issues of fact in these hearings would not interfere with the courts' use of the contempt power to protect the Constitution. ${ }^{87}$ As four Supreme

62. In re Oliver, 333 U.S. 257, 275 (1948). See also Cooke v. United States, 267 U.S. 517,536 (1925) ; Ex parte Terry, 128 U.S. 289 (1888).

63. See note 55 supra and accompanying text.

64. See text at notes 56-57 supra.

65. These situations are currently within the scope of FED. R. CRrM. P. 42 (a).

66. E.g., Cooke v. United States, 267 U.S. 517, 534 (1925); In re Savin, 131 U.S. 267 (1889) ; Ex parte Terry, 128 U.S. 289 (1888). FED. R. CRIM. P. 42, which states the procedure for punishing criminal contempts, substantially restates the law of these cases. See Notes of Advisory Committee on Rules, following rule 42, 18 U.S.C. 2549 (1952); Sacher v. United States, 343 U.S. 1, 7 (1952).

Although the terms of rule 42 (a) permit a judge to punish summarily contempts occurring in his actual presence, i.e. those which he has seen or heard, see notes 3,33 supra, the Supreme Court has determined that due process requires that summary punishment be restricted to cases where it is necessary to prevent "demoralization of the court's authority," and where the court's knowledge does not depend on collateral testimony or even on confession. Most false-swearing contempts are thus punishable only after hearing. E.g., In re Oliver, 333 U.S. 257, 275 (1948) ; Bowles v. United States, 50 F.2d 848 (4th Cir. 1931). The Supreme Court also requires that the hearing be public. In re Oliver, supra. And where the contempt has occurred before a judge-grand juror in secret grand jury proceedings, a different judge must preside at the contempt hearing. In re Murchison, 349 U.S. 133 (1955).

67. But sce Sacher v. United States, 343 U.S. 1, $20-23$ (1952) (dissenting opinion). Few cases have even discussed this point. Where they have done so, the criticism of jury trial as a severe interference with efficient criminal contempt power has assumed that jury trial would require use of a separate tribunal. See, e.g., Gompers v. Bucks Stove \& Range Co., 221 U.S. 418, 450 (1911) ; Bessette v. W. B. Conkey Co., 194 U.S. 324, 337 (1904) ; In re 
Court Justices have urged, in so far as the absence of jury trial is not required to make the contempt power effective, its use with a hearing but without a jury is not a permissible exception to the constitutional guarantee. ${ }^{68}$

Juries should therefore be provided in all criminal contempt proceedings unless the contempt occurs within the actual presence of the court and peremptory punishment is required to prevent "demoralization of the court's authority."69 The establishment of jury trial will provide protection for defendants without limiting the use of the contempt power. On the contrary, by eliminating the source of the judicial unease which has prompted irrational and confusing restrictions of contempt law, the use of juries will actually restore a sensible scope for the criminal contempt power.

\section{Proposals}

Jury trial may be provided by all levels of the federal judiciary through a variety of approaches. (1) The Supreme Court can recognize a right to jury trial in criminal contempt proceedings as a constitutional guarantee. ${ }^{70}$ (2) If the Supreme Court is reluctant to modify long-standing decisions and recognize a constitutional right, it can provide jury trials in criminal contempt hearings by exercising its supervisory power over federal criminal procedure. ${ }^{71}$ Recently, in Offutt $v$. United States, ${ }^{72}$ the Court exercised this power to remand a contempt case for a new hearing before a different judge. Although the judge before whom the contempt had been committed had the power to punish summarily, the Court thought it advisable to grant a new

Debs, 158 U.S. 564, 594-95 (1895). Under such circumstances the contempt power prubably would be impaired, see text at notes 54-57 supra. However, jury trial of contempt may be provided at the conclusion of the case in which the contempt has accurred or even during that case if the judge needs to know at once how to rule in the main case. See text at notes 71-78 infra. And the extra time required will probably not be substantial enough to curtail the effectiveness of the contempt power. Furthermore, there is no indication that the contempt power is impaired in situations where Congress currently requires jury trial.

68. Toledo Newspaper Co. v. United States, 247 U.S. 402, 425 (1918) (Holmes and Brandeis, JJ., dissenting); Offutt v. United States, 348 U.S. 11, 18 (1954) (Black and Douglas, JJ., concurring in separate opinion) ; Sacher v. United States, supra note 67, at 20-23 (Black and Douglas, JJ., dissenting).

The Supreme Court has balanced the courts' needs for contempt power against defendants' rights to protection and has concluded that defendant is entitled to all the Sixth Amendment rights except jury trial. See note 66 supra. This balancing process has also tipped in defendants' favor where First Amendment rights are involved. E.g., Craig v. Harvey, 331 U.S. 367 (1947) ; Pennekamp v. Florida, 328 U.S. 331 (1946); Eridges v. California, 314 U.S. 252 (1941) ; Maryland v. Baltimore Radio Show, 338 U.S. 912, 919 (1950) (Frankfurter, J., denial of certiorari). The Court's reasoning in those cases would seem to require a reappraisal also of defendant's right to jury trial in 42 (b) proceedings.

69. In re Oliver, 333 U.S. 257,275 (194S).

70. See notes 67-68 supra and accompanying text.

71. See McNabb v. United States, 318 U.S. 332, 341 (1943).

72. 348 U.S. 11 (1954). 
hearing. ${ }^{73}$ This decision, according the defendant more protection than the minimum the law then required, affords precedent for a similar decision to provide jury trial. The Court should amend Rule $42(\mathrm{~b})$ of the Federal Rules of Criminal Procedure to codify this result. ${ }^{7 \pm}$ (3) Appellate courts can follow a second rationale of the Offutt decision and remand criminal contempt cases for jury trials. The Supreme Court relied not only on its "supervisory authority over the administration of criminal justice in the federal courts" but also on "the importance of assuring alert self-restraint in the exercise by district judges of the summary power for punishing contempt."7s Surely lower appellate courts are as responsible as the Supreme Court for requiring "alert self-restraint" on the part of trial judges. ${ }^{76}$ (4) Finally, trial courts

73. Offutt v. United States, 348 U.S. 11, 13, 17 (1954). The contempt involved disrespect to a trial judge. The judge chose to wait until the end of the trial to impose punishment. Since summary punishment was not necessary to restore order, the Supreme Court felt that fairness required a hearing. The Court also ordered that a different judge preside at the hearing. It is not clear whether this result was based on procedural due process or the requirements of rule 42 (b). But sce Sacher v. United States, 343 U.S. 1 (1952).

74. See 1 U.S.C. $\$ 3771$ (1952) which establishes the Supreme Court's rule-making authority.

A change in rule $42(\mathrm{~b})$ could also be accomplished by direct congressional action. Although Congress has provided jury trials for some contempt proceedings, see note 4 supra, on the two occasions after 1789 when major contempt legislation was passed, congressional attention was directed to a current controversy which obscured the basic problem of jury trials for all contemnors. In 1831 Congress was concerned with Judge Peck's ill-tempered disbarring of an attorney for writing him a letter criticising a decision. See discussion in Nye v. United States, 313 U.S. 33 (1941) ; 7 Cong. Deb. 3, 10-30, 34-45 (1\$31) ; 6 Cong. DEB. 746 (1830). And in 1912, while considering the Clayton Act, Congress was primarily concerned with providing jury trial for striking laborers charged with violating injunctions. Congress therefore provided jury trials for contempts committed in violation of decrees where the contumacious conduct constitutes a separate crime. 18 U.S.C. $\$ 402$ (1952). The one exception to this provision, the case where the United States is a party, was made solely because the attorney-general feared that providing juries in these cases might interfere with Sherman Act prosecutions, and the committee felt it wisest to exclude jury trial "for the time being" while the antitrust legislation and the Interstate Commerce Act were in their "formative" stages. See 48 ConG. REc. \$776-809, 8878 , \&880, 8\$85, app. at 13 (1912).

The one time Congress broadly considered the jury trial problem, only delay thwarted a constructive attempt at solution. In 1895, due to protests after the Debs trial, In re Debs, 158 U.S. 564 (1895), Congress drew up a bill providing jury trial of all contempts occurring outside the court's presence. This bill passed in the Senate and, though favorably reported in the House, died there because no further action was taken before the end of the session. S. 2984, S. Rep. No. 827, 54th Cong., 1st Sess. (1896); H.R. ReP. No. 2471 54th Cong. 2d Sess. (1897). See 28 Cong. Rec. 6320-443 (1896).

For discussion of congressional power to provide jury trial in criminal contempt proceedings, see Michaelson v. United States, 266 U.S. 42 (1924); Frankfurter \& Landis, supra note 42 .

75. Offutt v. United States, 348 U.S. 11, 13 (1954).

76. See Matusow v. United States, 229 F.2d 335, 345-46 (5th Cir. 1956), where for the first time an appellate court reversed a contempt conviction and remanded the case to the trial court with directions to determine "whether the safeguards of the Fifth Amend- 
themselves can call in advisory juries to determine the facts in criminal contempt proceedings. Trial judges have broad discretion to use advisory juries, ${ }^{77}$ and this power has already been exercised in a criminal contempt case. ${ }^{78}$ Providing jury trials in criminal contempt proceedings gives a procedural answer to a procedural problem and secures Bill of Rights protection for criminal contempt defendants without crippling the substantive law of contempt.

ment ... and the protections of the Sixth Amendment ... shall be accorded to one upon a charge under ... [rule 42 (b) ]."

For a discussion of the doctrine of self-restraint in contempt law, see text at notes 5-9 supra.

77. See Youtsey v. United States, 97 Fed. 937 (6th Cir. 1899) (jury called to determine defendant's sanity to stand trial) ; United States v. Fore, 38 F. Supp. 140 (S.D. Cal. 1941) (same). See also 5 Moore, Federal Practice $\int 39.10$ (2d ed. 1951); Guggenheim, A Notc on the Advisory Jury in Federal Courts, 8 FED. B.J. 200 (1947).

78. In re Steiner, 195 Fed. 299 (S.D.N.Y. 1912). 